\title{
The Strategic Management as a Factor of Customer Satisfaction in the Foodservice Industry in Sarajevo Canton
}

\author{
FERDA GURSEL \\ International University of Sarajevo, Bosnia \& Herzegovina \\ gursel.a@gmail.com \\ SENAD BUSATLIĆ \\ International University of Sarajevo, Bosnia \& Herzegovina \\ sbusatlic@ius.edu.ba \\ SONJA KETIN \\ Faculty of Technical Science, Novi Sad, Serbia \\ ketin.sonja@gmail.com \\ SEMSUDIN PLOJOVIĆ \\ International University of Sarajevo, Bosnia \& Herzegovina \\ s.plojovic@uninp.edu.rs
}

This study can help to explore and measure food service quality, and the effect of strategic management factor on the foodservice industry in Bosnia and Herzegovina, and level their impacts on customer satisfaction. This study was structured in two parts as a literature review and survey research. And the data were collected primarily by considering the quality. The period of collecting the data from adapting to the questionnaire and applications of the samples for employing the modified version took eight months. The participants were the customers, who were chosen randomly, in the restaurants and cafes in Sarajevo. 120 surveys applied in this research, the diversity of restaurants and cafes were also chosen randomly, by considering the equal diversities, such as luxury restaurants, fast food restaurants, and cafes which serve foods. The data were analyzed by using spss statistic software for descriptive statistic, for variance analysis by ANOvA, Turkey and $t$-test methods and for analyzing of significant differences by Post Hoc LSD and Levene's tests. According to survey results, the customers are seen as satisfied with the quality of foods and their tastiness and also attributes of restaurants. However, they stated that the service quality in the restaurants is needed to be improved. Particularly, while increasing the income and age of participants, their expectations from the service standards and restaurant attributes and conveniences have been increased. The participants who prefer a longer time to spend in the restaurant, 
also caring more about the ambiance of restaurants and feeling comfortable themselves while staying there. And the most of reason for going to the restaurant is for a social occasion. And interestingly, $57 \%$ of participants are going 'rarely' to restaurants, and $42 \%$ of participants have less than $1000 \mathrm{KM}$ per month, the two results can be evaluated together to explain the reasons of each other.

Key words: food industry, food service, service quality, restaurant management, strategic management, customer satisfaction https://doi.org/10.26493/1854-4231.14.238-248

\section{Introduction}

The main objective of this study is to measure the customer satisfaction from food service in Sarajevo. The reviewed literature was considered, especially Kivela's, Inbakaran's, and Reece's (1999) dining satisfaction model was set in this research, and it was formulated the hypotheses accordingly.

н1 Restaurants in Sarajevo are having a low satisfactory level in food service,

н2 There are significant differences between food and service quality in restaurants,

н3 Food service quality is dependent on the background of the staff management model of the restaurant

${ }_{4} 4$ Development of food services is associated with the success of strategic management of the restaurants.

Finally, the author wanted to examine how customer satisfaction differs among the demographic groups in the survey participants who are a customer of restaurants in Sarajevo, and thus the fifth hypothesis was developed.

$\mathrm{H} 5$ There is a significant difference in satisfaction level from food service and restaurant attributes, among the participants related to their demographic variables.

In the questionnaire demographic questions are dependent variables, first and second section of survey are consist of independent variables and the last question as control variable is to measure over all responds.

\section{Instrumentation}

A questionnaire related to food service quality was specially designed to collect the data related to different aspects of strategic

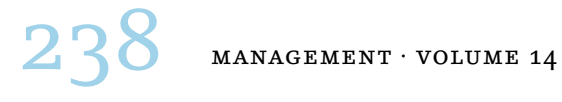


management functioning within a restaurant. The SERVQUAL instrument for measuring service quality, which was developed by Parasuraman, Berry, and Zeithaml (1988), and its modified version and linear model which was employed by Kivela, Inbakaran, Reece (1999), adopted for this study. The structure of the questionnaire was consist of 91 questions totally, first six questions are about demographic questions as independent variables, then the instrument was applied which consist of 28 items as dependent variables were repeated for each to sections such as consumers' expectations, their perceptions, and importance of the attributes for customers. The sub-variables were about the 'food, service, restaurant appearance, convenience and what should a restaurant offer.' The questions in this part were designed based on the Likert Scale from 5 (very high) to 1 (very low). And at the end of the questionnaire, it was asked to customers that 'will you come to the restaurant again?' to evaluate overall perceptions and to control the questionnaire.

\section{Model of Research}

The adopted instrument and the research model were tested with twenty surveys as 'sample questionnaire' in the restaurants in Sarajevo (see the model in the Appendix I). The participants were not willing to respond to two demographic questions, about their occupation and education background. Then, the questionnaire was modified by reducing these two questions and employed in Sarajevo. The research was conducted on a convenient questionnaire, and the 120 participants who were the customer of restaurants in Sarajevo, were selected randomly. The survey was voluntary based and the volunteers motivated by a pollster to fill in the questionnaire in actual time, in different restaurants and cafes. The restaurants were also selected randomly with consideration of the level of their diversities.

The goal of each research is not to eliminate potential threats, but rather to reduce them to the minimum level, and therefore, it is almost impossible to have $100 \%$ of confirmed validity.

According to Creswell (2008), there are three forms of validity:

- Content validity,

- Construct validity,

- Concurrent validity.

Out of the three forms of validity, the first two forms are the most sophisticated and recommended for social studies. Content validity 
investigates whether items measure what they should measure $(\mathrm{Mu}-$ sic 2007). The validity test of this study was examined by 20 sample surveys. The participants confirmed the entire questionnaire, except for two demographic questions. They refused to answer the two questions about their 'occupation' and 'education.' Thus, these two questions were removed from the questionnaire with the suggestion of mentor of this research, then the adapted instrument and its developed version in Kivela's, Inbakaran's, and Reece's (1999) models, was applied in this study.

The data collection is an essential component of conducting research. Even though it might sound simple, it is a difficult and timeconsuming task, and it is rather hard to say what the best method for completing that task is (Music 2017). It does not only include distributing the questionnaire to participants, but also, the process of preparing and collecting the data for further usage.

This study includes primary data sources, which was collected to specifically address the problem stated at the beginning of the research. The data was collected through surveying this study, by using advantages of the primary data research which is more insight on qualitative and quantitative issues, by controlling the research design and the information. On the other hand, there were disadvantages to various costs of data. Primary data collection was expensive and time-consuming, and it was difficult to prepare a strong research plan in order to meet the deadlines.

The descriptive statistics and inferential statistical analysis were performed on the collected data. Frequencies and percentages were calculated for categorical and dependent variables while mean values, range, and standard deviations were calculated for scale values. In the data analyses, different parametric statistical methods were employed and parameters evaluated by using spss statistic software. For variance analysis by ANova (Analysis of Variance), Turkey and $t$ test methods and for analyzing of significant differences by Post Hoc LSD (Least Significant Difference) and Levene's tests were applied in this study.

\section{Results and Discussion}

The Statistical Package for Social Sciences (spss), Version 25 and Microsoft Excel 2017 were used for analyzing data received from the questionnaire. The inferential statistics methods that were used comprised of: Method of Correlation Coefficient that measured the strength of association between the selected variables; the independent samples $t$-test, Turkey and ANova were computed to examine

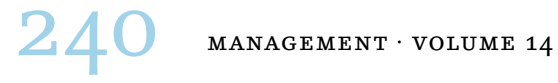



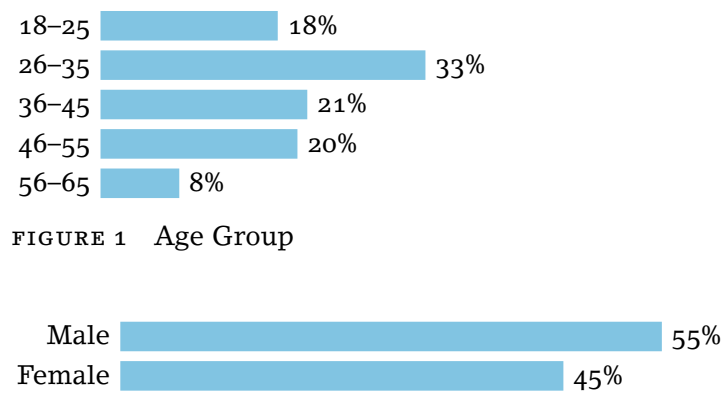

FIGURE 2 Gender Distribution

the existence of hypothesized difference among the demographic groups of customer satisfaction on food service quality and explain their variance in general. Then Post Hos LSD and Levene's test were applied to see the least significant difference among each group.

The purpose of the study was to examine the extent to customer satisfaction from food service in the restaurant in Sarajevo. The objectives on which study was focused are presented below.

The biggest part of the participants who filled to the survey in the ages between 26 and 55 with $74 \%$. Most of the customer in restaurants and cafes are in mid ages as it was observed. The results confirmed the objective observations.

As it is seen in figure 2, among the people who accepted to fill the survey, $55 \%$ of them were male, and it can be said that males are spending time out of home or work and preferring dining in the restaurants more than females.

The customer who accepted to fill the survey, the biggest rate is less than $1000 \mathrm{KM}$ (convertible mark) income potential with $42 \%$ and the second biggest rate of income is between $1000 \mathrm{KM}$ and $2000 \mathrm{KM}$ with $25 \%$. This result shows that the people who have a lower income, they mostly spend time in a restaurant and cafes. In another word, it can be said that the people who have higher income or a better job, they don't have time to go out or restaurant to spend a long time, not similar as the others.

The frequency of dining out is quite low according to question re-

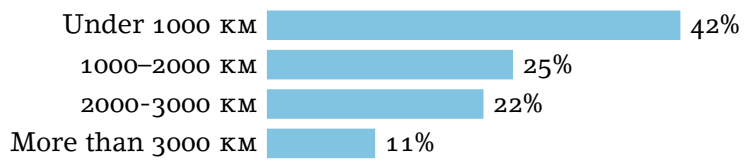

FIGURE 3 Distribution of Income 


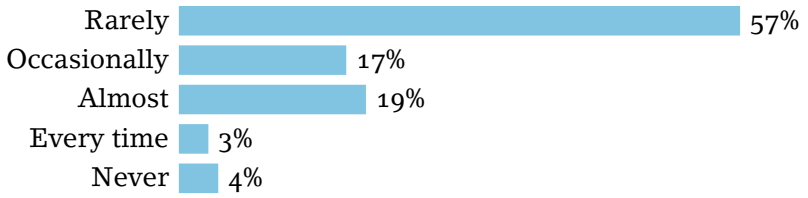

FIGURE 4 Dining Out Frequency

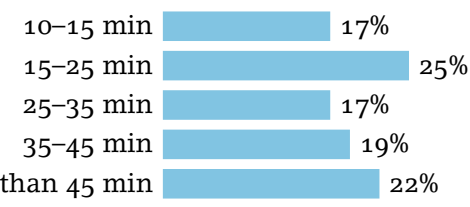

More than $45 \mathrm{~min}$

FIGURE 5 Spending Time in a Restaurant

sult. $57 \%$ of respondents have responded as 'rarely' dining out. It is quite interesting that lower income person who became subject of present study is higher than higher income persons. And also, this question is measuring for eating out of home, not measuring the spending time in cafes or somewhere else. Therefore, they might be argued that they rarely dining out. The next question about 'spending time in restaurant' will light the wonderment about spending time in restaurants or cafes.

The answers to this question are given as $25 \%$ for $15^{-25} \mathrm{~min}$ and $22 \%$ for $45 \mathrm{~min}$ and up, and it can be realized that the people in Sarajevo prefer longer to stay in the restaurant. It might be thought that their reasons for going to a restaurant not only for feeding themselves. The main reason can be seen clearly in the next question.

This question is significant for local people in Sarajevo, regarding to their cultural habits. As it is seen in figure 6, 39\% of participants say that their reason for going to the restaurant is for 'social occasion' and $26 \%$ of others says that it is for their 'convenience.' This shows what are their sociocultural characteristics and attributes. They like socializing, convenience and they have outgoing personality. The means of all items and standard deviations are seen in the table 1.

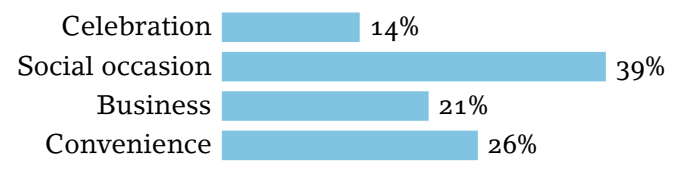

FIGURE 6 Reasons for Going in a Restaurant

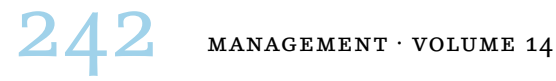


TABLE 1 Expectations-Perceptions from the Restaurant and Importance of Attributes

\begin{tabular}{|c|c|c|c|c|}
\hline Category & Item & (1) & (2) & (3) \\
\hline \multirow{7}{*}{$\begin{array}{l}\text { Expectations: } \\
\text { perceptions from } \\
\text { the food and im- } \\
\text { portance of at- } \\
\text { tributes }\end{array}$} & Presentation of food & $\begin{array}{r}3.358 \\
(1.075)\end{array}$ & $\begin{array}{r}3.258 \\
(0.974)\end{array}$ & $\begin{array}{r}3.666 \\
(1.117)\end{array}$ \\
\hline & Menu item variety & $\begin{array}{r}3.533 \\
(0.978)\end{array}$ & $\begin{array}{r}3.350 \\
(0.949)\end{array}$ & $\begin{array}{r}3.716 \\
(1.030)\end{array}$ \\
\hline & Nutrition food & $\begin{array}{r}3.766 \\
(1.082)\end{array}$ & $\begin{array}{r}3.550 \\
(1.035)\end{array}$ & $\begin{array}{r}4.000 \\
(1.130)\end{array}$ \\
\hline & Tastiness of food & $\begin{array}{r}3.833 \\
(1.094)\end{array}$ & $\begin{array}{r}3.733 \\
(1.018)\end{array}$ & $\begin{array}{r}4.066 \\
(1.066)\end{array}$ \\
\hline & Food quality & $\begin{array}{r}3.875 \\
(1.049)\end{array}$ & $\begin{array}{r}3.600 \\
(1.103)\end{array}$ & $\begin{array}{r}4.050 \\
(1.129)\end{array}$ \\
\hline & Freshness of food & $\begin{array}{r}3.800 \\
(1.057)\end{array}$ & $\begin{array}{r}3.650 \\
(0.992)\end{array}$ & $\begin{array}{r}3.908 \\
(1.107)\end{array}$ \\
\hline & Temperature of food & $\begin{array}{r}3.866 \\
(1.084)\end{array}$ & $\begin{array}{r}3.650 \\
(1.142)\end{array}$ & $\begin{array}{r}4.150 \\
(1.050)\end{array}$ \\
\hline \multirow{7}{*}{$\begin{array}{l}\text { Expectations: } \\
\text { perceptions from } \\
\text { the service and } \\
\text { importance of at- } \\
\text { tributes }\end{array}$} & Polite, friendly, helpful staff & $\begin{array}{r}3.750 \\
(1.094)\end{array}$ & $\begin{array}{r}3.483 \\
(0.987)\end{array}$ & $\begin{array}{r}3.816 \\
(1.028)\end{array}$ \\
\hline & Attentive staff & $\begin{array}{r}3.808 \\
(1.023)\end{array}$ & $\begin{array}{r}3.491 \\
(0.978)\end{array}$ & $\begin{array}{r}3.875 \\
(0.903)\end{array}$ \\
\hline & Staff greeting customers & $\begin{array}{r}3.700 \\
(1.025)\end{array}$ & $\begin{array}{r}3.475 \\
(0.978)\end{array}$ & $\begin{array}{r}3.791 \\
(0.924)\end{array}$ \\
\hline & Efficient service & $\begin{array}{r}3.808 \\
(1.023)\end{array}$ & $\begin{array}{r}3.550 \\
(1.002)\end{array}$ & $\begin{array}{r}3.766 \\
(1.001)\end{array}$ \\
\hline & Staff are willing to serve & $\begin{array}{r}3.700 \\
(1.025)\end{array}$ & $\begin{array}{r}3.425 \\
(1.018)\end{array}$ & $\begin{array}{r}3.783 \\
(1.054)\end{array}$ \\
\hline & Staff have food/beverage knowledge & $\begin{array}{r}3.733 \\
(1.034)\end{array}$ & $\begin{array}{r}3.433 \\
(1.001)\end{array}$ & $\begin{array}{r}3.650 \\
(1.058)\end{array}$ \\
\hline & Sympathetic handling of complaints & $\begin{array}{r}3.716 \\
(1.030)\end{array}$ & $\begin{array}{r}3.408 \\
(1.057)\end{array}$ & $\begin{array}{r}3.758 \\
(1.004)\end{array}$ \\
\hline
\end{tabular}

\section{Conclusion and Recommendations}

In this study, it was investigated to the food service quality and its effects of customer satisfaction Bosnia and Herzegovina and as a case study in Sarajevo. However, it is clearly seen that the service quality and standards are not satisfied, in this research. Thus, it was aimed to investigate and determine the existing condition, then raise awareness about food service quality to be improved. The statistical results are showing that the hypothesis of this study was accepted, especially in relation to the independent demographic variables.

According to overall survey results, the customers are not complaining in accordance with the reality about the service quality. 
TABLE 1 Continued from the previous page

\begin{tabular}{|c|c|c|c|c|}
\hline Category & Item & (1) & (2) & (3) \\
\hline \multirow{8}{*}{$\begin{array}{l}\text { Expectations: } \\
\text { perceptions from } \\
\text { the ambiance } \\
\text { and importance } \\
\text { of attributes }\end{array}$} & Level comfort in the restaurant & $\begin{array}{r}3.666 \\
(0.973)\end{array}$ & $\begin{array}{r}3.458 \\
(0.906)\end{array}$ & $\begin{array}{r}3.775 \\
(0.939)\end{array}$ \\
\hline & Level of noise in the restaurant & $\begin{array}{r}3.683 \\
(0.934)\end{array}$ & $\begin{array}{r}3.450 \\
(0.896)\end{array}$ & $\begin{array}{r}3.708 \\
(1.032)\end{array}$ \\
\hline & View from the restaurant & $\begin{array}{r}3.541 \\
(0.897)\end{array}$ & $\begin{array}{r}3.383 \\
(1.014)\end{array}$ & $\begin{array}{r}3.625 \\
(1.004)\end{array}$ \\
\hline & Cleanliness of the restaurant & $\begin{array}{r}4.008 \\
(1.024)\end{array}$ & $\begin{array}{r}3.641 \\
(0.977)\end{array}$ & $\begin{array}{r}4.000 \\
(1.152)\end{array}$ \\
\hline & Dining privacy & $\begin{array}{r}3.458 \\
(1.052)\end{array}$ & $\begin{array}{r}3.375 \\
(0.944)\end{array}$ & $\begin{array}{r}3.525 \\
(0.969)\end{array}$ \\
\hline & Restaurant's temperature & $\begin{array}{r}3.625 \\
(1.045)\end{array}$ & $\begin{array}{r}3.525 \\
(1.060)\end{array}$ & $\begin{array}{r}3.683 \\
(0.987)\end{array}$ \\
\hline & Restaurant appearance & $\begin{array}{r}3.708 \\
(0.901)\end{array}$ & $\begin{array}{r}3.525 \\
(1.036)\end{array}$ & $\begin{array}{r}3.725 \\
(1.068)\end{array}$ \\
\hline & Staff appearance & $\begin{array}{r}3.491 \\
(1.069)\end{array}$ & $\begin{array}{r}3.508 \\
(0.995) \\
\end{array}$ & $\begin{array}{r}3.750 \\
(1.006) \\
\end{array}$ \\
\hline \multirow[t]{2}{*}{ Convenience } & Handling of telephone reservations & $\begin{array}{r}3.691 \\
(0.914)\end{array}$ & $\begin{array}{r}3.508 \\
(0.898)\end{array}$ & $\begin{array}{r}3.608 \\
(1.031)\end{array}$ \\
\hline & Parking convenience & $\begin{array}{r}3.733 \\
(0.976) \\
\end{array}$ & $\begin{array}{r}3.541 \\
(0.986)\end{array}$ & $\begin{array}{r}3.758 \\
(1.012)\end{array}$ \\
\hline \multirow[t]{4}{*}{ A restaurant ... } & Offers a new dining experience & $\begin{array}{r}3.408 \\
(1.008)\end{array}$ & $\begin{array}{r}3.233 \\
(0.941)\end{array}$ & $\begin{array}{r}3.425 \\
(0.931)\end{array}$ \\
\hline & Offers food of a consistent standard & $\begin{array}{r}3.708 \\
(0.956)\end{array}$ & $\begin{array}{r}3.400 \\
(0.834)\end{array}$ & $\begin{array}{r}3.775 \\
(0.920)\end{array}$ \\
\hline & Feels comfortable to eat there & $\begin{array}{r}3.908 \\
(0.925)\end{array}$ & $\begin{array}{r}3.608 \\
(0.843)\end{array}$ & $\begin{array}{r}3.783 \\
(0.980)\end{array}$ \\
\hline & $\begin{array}{l}\text { Offers service of a consistent stan- } \\
\text { dard }\end{array}$ & $\begin{array}{r}3.766 \\
(0.967)\end{array}$ & $\begin{array}{r}3.533 \\
(0.916)\end{array}$ & $\begin{array}{r}3.741 \\
(1.024)\end{array}$ \\
\hline
\end{tabular}

Notes Column headings are as follows: (1) expectations, (2) met the perceptions, (3) importance of attributes. Mean values (standard deviation in parentheses).

Their response is seen in the descriptive statistics and on average as '3.491' of '5,' based on the Likert Scale of the research instrument in this study. On the other hand, they are expecting that the food service quality needs to be improved.

However the outcomes in this study show that the participants are mostly don't consider the service quality, they just focused on the food attributes. It will be seen in detail and understood the results while evaluating the findings.

Based on gender differentiation, women are demanding higher standards in all variables. They are expecting more, and they are meeting less for their perceptions. But, interestingly, in the last part

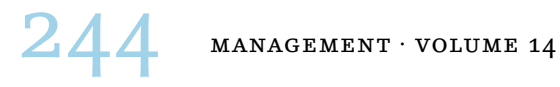


of the survey, the participant responded to the question that 'Will you come to the restaurant again?' and the answers as 'No' were mostly came from men.

Income is one of the main factors for demanding higher quality and standards in foods, service attributes and conveniences from the restaurants. For example, parking convenience is one of the main attributes for higher income holders, which they think that it is a problem that they usually meet this problem.

Dining out frequency, as a variable, has been observed in 'rarely' with $57 \%$ rate. These results can be explained with income and revenues. Owing to the fact that $42 \%$ of the participants have less than $1000 \mathrm{KM}$ per month, and 25\% of them have between 1000 to $2000 \mathrm{KM}$. Dining out can be not affordable in so frequent. Another result from this part is that the participants, who are frequently dining out, are not satisfied in general from the service, attributes and etc.

The time spent in a restaurant is effected for different reasons. There was a variety of restaurants and cafes in this research. From the higher standard restaurants to the fast food restaurants, and in some café' which serve food in, were chosen in this study to collect reliable data. It was not an object to analyze the standards of restaurants differentiations in this study, but in the future study, it can be researched in detail regarding their potential customer profiles.

In this study, the participants who spent a long time, such as 45 minutes and more have more expectations than the others. And based on the type of standards of the restaurants, the time spent is changing. The participants who spent a short time in a restaurant, while dining, they don't have a consideration on restaurant ambiances, conveniences, and other attributes. In luxury and convenient restaurants, the customers spending more time, as expected. And the customers are satisfied with the services and ambiances in this luxury restaurants.

In any parameters, the local people in Sarajevo, they usually prefer to spend a long time in restaurants, if it is compared to the other societies. Because their reasons for going to the restaurants are mostly for social occasions, this will be explained in detail below.

Many factors in this study are related to each other. The reason for going restaurants are usually for the social occasion as it was mentioned. For most of the Bosnian people, dining in a restaurant is a social occasion. Antony (2011) stated that most people eat at restaurants and food service operations for enjoyment and entertainment. But in Bosnia, it seems as social occasion more than the other societies. If it is evaluated with the parameter of dining our frequency, 
which was obtained as 'rarely,' they mostly considered as a social activity. These results are explaining many things that may be related to cultural and other effects, which is needed to be analyzed in future studies in different aspects in related fields.

In the last part of the survey, it was asked to the participants that 'will you come to the restaurant again?' And 70\% of them replied as 'Yes.' This the most critical question in over all that to show the culture and mentality. It can be explained that the Bosnian people are so modest, fewer expectations or there are a few alternatives to go. But, it is the most accurate explanation can be on cultural values.

In order to cultural, economic and other reasons, expectations of participants are quite modest. Apart from the survey questions, during the conversation meanwhile employing the surveys, they were mentioning clearly about their approaches. They said that they like local food, and they only consider their tastes and being affordable; they are not caring about the presentation of the food and their service quality. It might be because of the cultural and economic effects, and sociopolitical situations of B\&H and Canton Sarajevo, keep the people in a conservative lifestyle. This factor also might affect food service standards, not to be improved. Soon or later, it will be changed. Tourism capacity of $\mathrm{B} \& \mathrm{H}$ and Canton Sarajevo is increasing day by day. When the mentality integrated into the global culture, expectations of the existing customers and potential customers will be increased, and they will demand a higher standard for food services.

One other interesting finding that there is neither tourism school nor school for service in the hospitality industry in $\mathrm{B} \& \mathrm{H}$. Therefore, the service staff in the foodservice sector has no chance to be educated and trained to improve their skills and knowledge. And, this might be one of the key reasons for insufficient food service quality.

According to Knutson and Patton (1993) service quality is a strong motivator for choosing a restaurant. The food quality, tastiness, freshness and etc. are just minimum requirements for all restaurants. Besides the ambiance and restaurant attributes, the service quality is attracting the customers.

The food quality, tastiness and varieties of local foods have a chance to be opened to the global market. Bosnia and especially Sarajevo have the capacity to be a center of gastronomy tourism. However, it cannot be succeeded without improving the service quality to international standards.

Lastly, the survey has totally 91 different types of questions and some of them are repeating under the different variables. But the participants are responded to each of those questions objectively and

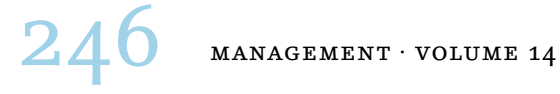


in detail without hesitation, which can be seen in the results and which is confirming the reliability of this research. Therefore, the variable of 'spending time in a restaurant' has to be analyzed in this perspective. As it is seen above, in almost all criteria this variable have significant differences. According to demographic variables, duration and reason for spending time in a restaurant are changing.

\section{Recommendations}

During the studying period in Sarajevo, while observing to the society as a foreigner, it was realized that the local people in Bosnia, prefer to spend a longer time in the restaurants or cafes, if you compare the other societies and cultures. And during the employing the surveys in the restaurants, it was had a chance to interview with the owners or managers of them. They mentioned about the sectorial problems, lack of qualified staff, and no institution to be educated for service in the hospitality industry, which I tried to mention in the text. These outcomes were unpredictable and the information's were out of the topic, and they were not in the objective of this study, but they can be researched and analyzed in the future studies.

There was a variety of restaurants and cafes in this research. From the higher standard restaurants to the fast food restaurants, and in some café' which serve food in, were chosen in this study to collect reliable data. It was not an object to analyze the standards of restaurants differentiations in this study, but in the future study, it can be researched in detail regarding their potential customer profiles.

Tourism capacity of B\&H and especially in Canton Sarajevo is increasing and the existing customers and potential customers will be increased in the near future, and they will demand a higher standard on food services. Thus, immediately it has to be established as an institution for service in the hospitality industry and tourism. Qualified staff for service is needed the tourism and food service sector.

The cultural effects on these research outcomes must be investigated professionally by the researchers, experts and academicians in sociopsychology, economy and other social sciences fields. And all over the outcomes might evaluate and considered by decision makers to open way of the sectorial improvement.

\section{References}

Creswell, J. W. 2008. Educational Research: Planning, Conducting, and Evaluating Quantitative and Qualitative Research. (3rd ed.). Upper Saddle River, NJ: Pearson Education. 
David, F. R. 2011. Strategic Management: Concepts and Cases. 13th ed. London: Pearson Education.

Kivela, J., R. Inbakaran, and J. Reece. 1999. 'Consumer Research in the Restaurant Environment, Part 1: A Conceptual Model of Dining Satisfaction and Return Patronage.' International Journal of Contemporary Hospitality Management 11 (5): 205-22.

Knutson, B. J., and M. E. Patton. 1993. 'Restaurants Can Find Gold Among Silver Hair: Opportunities in the 55+ Market.' Journal of Hospitality \& Leisure Marketing 1 (3): 79-90.

Music, A. 2017. 'The Influence of Employees' Perception of Performance Appraisal on Their Work Outcomes.' Master thesis, International University of Sarajevo.

Parasuraman, A., L. Berry, and V. Zeithaml. 1988. 'Servqual: A Multiple Item Scale for Measuring Customer Perception of Service Quality.' Journal of Retailing 64 (1): 12-40.

This paper is published under the terms of the Attribution-

NonCommercial-NoDerivatives 4.0 International (CC BY-NC-ND 4.0)

License (http://creativecommons.org/licenses/by-nc-nd/4.o/). 